\title{
Hydro Geo-Electrical Investigation in Gombe Town and Environs, Northeastern Nigeria
}

\author{
${ }^{1}$ ARABI, A. S.; ${ }^{2}$ NUR, A.; ${ }^{1}$ DEWU, B.B.M. \\ ${ }^{1}$ Center for Energy Research and Training,Ahmadu Bello University, Zaria.-Nigeria.Azuftamas@Gmail.com \\ ${ }^{2}$ Federal University of Technology, Yola-Nigeria
}

\begin{abstract}
Thirty three vertical electrical soundings (VES) were conducted around Gombe and environs, employing Schlumberger array with a maximum electrode separation of $\mathrm{AB} / 2=200 \mathrm{~m}$ to determine locations favorable for sitting boreholes. The data obtained were interpreted using the partial curve matching technique and software (offix) for resistivity data interpretation. From the result, it was found that twenty one of the VES points are three layers while twelve are four layers. The first layers have thicknesses ranging from $0.8 \mathrm{~m}$ to $16.1 \mathrm{~m}$, the second and third layer have thicknesses ranging from $0.994 \mathrm{~m}$ to $149 \mathrm{~m}$ and $11.7 \mathrm{~m}$ to $108.2 \mathrm{~m}$, respectively while the fourth layer had thickness that extended beyond the probing depth. A correlation of the curves with existing lithologic log from boreholes in the study area suggests that the major lithologic units penetrated by the sounding curves were laterite, clay, shale, sandstone and sandy clays. The sandy clay and sandstone constitute the aquifer zones with resistivity range of $28 \mathrm{ohm}-\mathrm{m}$ to $84 \mathrm{ohm}-\mathrm{m}$ for clay, $240 \mathrm{ohm}-\mathrm{m}$ to $501 \mathrm{ohm}-\mathrm{m}$ for sandstone, $967 \mathrm{ohm}-\mathrm{m}$ to 1008 ohm-m for sandy clay. Others are $2069 \mathrm{ohm}-\mathrm{m}$ to $9607 \mathrm{ohm}-\mathrm{m}$ for the calcareous and the laterite units and 17456 $0 \mathrm{hm}-\mathrm{m}$ for the compacted sands. The direction of groundwater flow in the area was found to be northwest-southeast, average fitting error, $\mathrm{pH}$ and conductivity are 6.138 percent, 7.02 and $72.16 \mathrm{ohm} \mathrm{cmP}^{-1 \mathrm{P}}$ respectively. @ JASEM
\end{abstract}

Resistivity survey was employed in this work to determine locations suitable for borehole construction because it can favorably locate water-bearing layer. The area is bounded by Latitude $10 \mathrm{P}^{0}{ }^{\mathrm{P}} 00 \mathrm{P}^{\mathrm{I}} \mathrm{P}_{\text {to }}$ $10 \mathrm{P}^{0 \mathrm{P}} 30 \mathrm{P}^{\mathrm{I}} \mathrm{P}$ and Longitude $11 \mathrm{P}^{0 \mathrm{P}} 00 \mathrm{P}^{\mathrm{IP}}$ to $11 \mathrm{P}^{0 \mathrm{P}} 45 \mathrm{P}^{\mathrm{I}}$ ${ }^{\mathrm{P}} \mathrm{E}$ (Fig.1). It covers parts of Gombe, Yamaltu-Deba, Akko and Kwami local government areas of Gombe State-Nigeria. The overall success of groundwater supply development often depends on borehole sitting, the greater the sitting successes, the fewer boreholes that have to be drilled to achieve the project objectives. Borehole sitting success has improved and become more cost effective in recent years with the introduction of new geophysical techniques and improved instrumentation with greater resolution. The study reported here has allow the determination of the pattern of resistivities and depth variation of geologic materials in the area, relating the resistivities and thicknesses of the layers to water bearing layer of such units, delineation of units that are favorable for ground water development and the correlation of borehole lithologies and geoelectric section. A total of nineteen productive boreholes were successfully drilled after the survey because the target was to drill boreholes that must be equipped with hand pumps with designed depth of less than $70 \mathrm{~m}$.

\section{GEOLOGY OF THE STUDY AREA}

The study area has good road network and prominent on its landforms are the Wade, and the Gombe hills, it falls within a stretch of the Benue Trough known as
Zambuk ridge. The stratigraphy consists of the Alluvium, the Kerri Kerri Formation, Gombe Formation, Pindiga Formation, Yolde Formation, Bima Formation and the basement rocks as the oldest. Alluvium includes most soils and comprises those deposits formed in- situ by the chemical and physical decomposition of the bedrocks. Alluvium is generally poorly developed over the arenaceous member of the Cretaceous Formation in the study area, the extent of alluvium cover increases westward but it can be estimated that $10 \%$ of the Gombe Formation is covered by alluvium (Carter. et al 1963).

The Kerri-Kerri Formation was laid down in a continental environment ranging from lacustrine to deltaic, being derived from the weathering of the basement rocks as well as of Cretaceous Sedimentary Formations. It outcrops in the western part of the study area and lies unconformably on the Gombe Formation. In the western part of the plateau, which coincides with the western edge of the area, the Kerri-Kerri Formation overlies the basement complex, but the contact is almost completely masked by abundant alluvial deposits. The maximum thickness of this formation is about 200m (Carter et $a l, 1963)$. The formation has not been subjected to folding and has the lowest fracture density of all the Formations present in area. This is probably because it was laid down after the main tectonic phase has occurred, and on the poorly cemented nature of the lithological components of its upper part. 


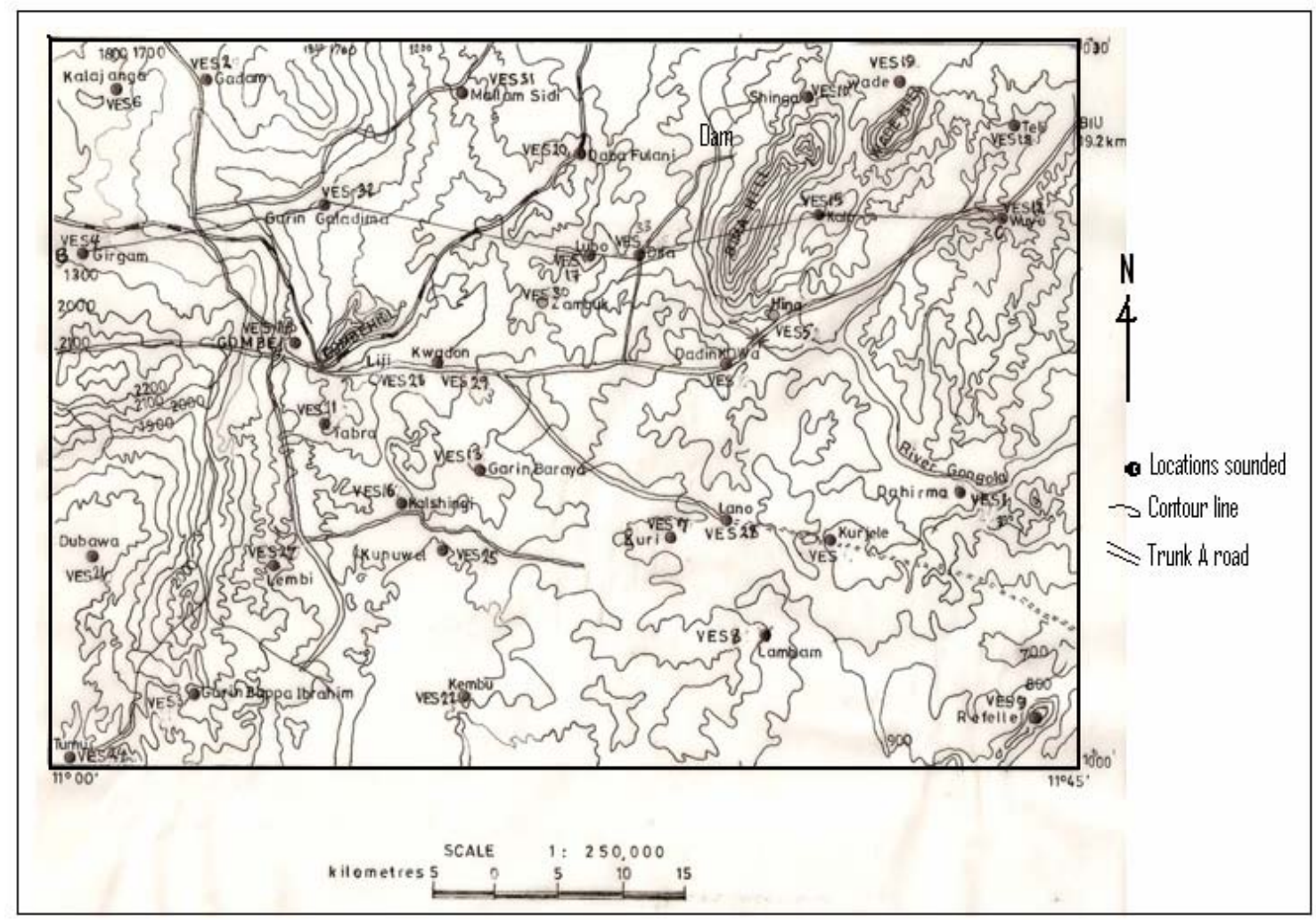

Fig. 1: Topographic map of the study area (GSN 1984)

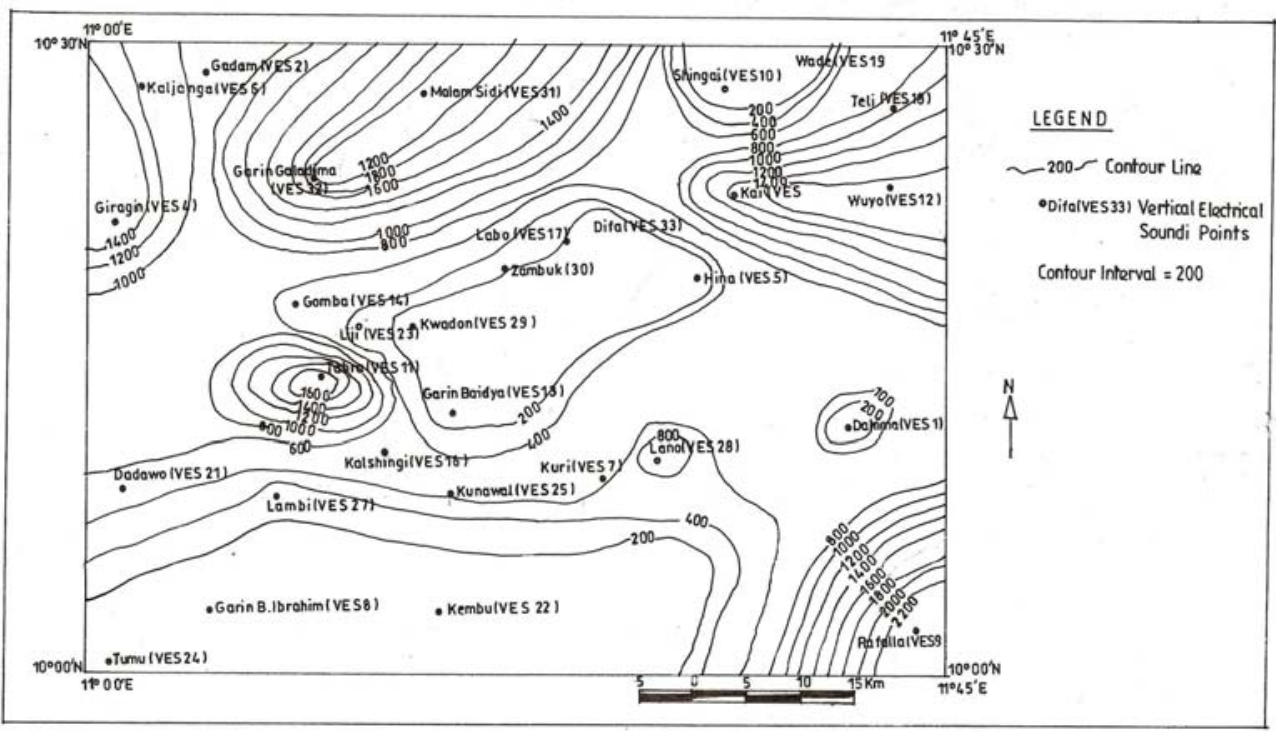

FIG.2: ISO-RESISTIVITY MAP OF $A B / 2=80 \mathrm{~m}$

* Corresponding author: Arabi, A. S. 
The Gombe Sandstone outcrops in a narrow northsouth belt on the western part of the study area where it unconformably lies on shale and limestone of the Pindiga Formation and is unconformably covered by the Kerri-Kerri Formation. The Gombe Formation is a continental sequence of sandstone, shale, siltstones and ironstones, with maximum thickness of $300 \mathrm{~m}$ and its sequence can be divided into two parts: The Upper $223 \mathrm{~m}$ mainly consisting of sandstones and the lower which consist of shale and contains ironstones layers up to $200 \mathrm{~m}$ thick (Carter et al, 1963). The Pindiga Formation conformably overlies the Yolde Formation, while an unconformity separates it from the overlying Gombe Sandstone (Upper Maestrichtian). It outcrops and cuts across the study area in a north-south direction, it is also found in the southeast and the northeastern part.

The Pindiga Formation consists of a series of marine, blue-black shale with interblended fossilferous limestone at the base (Carter et al, 1963). The Yolde Formation conformably overlies the massive coarse sandstones of the Bima Formation (AlbianCenomanian) and is conformably bounded at the top by the marine shale of the Pindiga formation. The Yolde Formation is present in the study area around the south-east, the central area and the north, it constitutes the transition facies between continental and marine sedimentation.

The Bima formation is the oldest, most extensive and thickest of the Cretaceous sedimentary Formations in northeastern Nigeria, outcropping in northwest and south of the study area. The Bima Formation rests directly on the Precambrian basement complex and is covered without any break by the Yolde Formation in the Zambuk ridge area. The Bima Formation consists of Yellow-brown, massive cross-bedded feldspartic sand stones, with some white saccharoid sandstones, ferruginous sandstones and pebble bands. The age of this formation is uncertain, however, various pointers indicate that it runs from Upper Albian to Lower Turonian (Carter et al, 1963). The basement complex includes all the pre-Mesozoic rocks and is thus the oldest formation of the Nigerian stratigraphic series. It is composed mainly of granites, gneisses and migmatites with subordinate basic rocks. In the study area, remnants of highly metamorphosed sedimentary rocks are present here and there, mainly as xenoliths. In the northeastern part of the area it outcrops as biotite and coarse porphyritic granite and as anatetic migmatites around the Gombe-Hill (Fig.1).

\section{DATA ACQUISITION INTERPRETATION}

AND

An ABEM SAS 300C Terrameter was used to acquire field data and schlumberger configuration layout was adopted in which both current and potential electrodes were laid in a straight line with the current electrode in the center. From the value of the potential difference, the current applied and also the electrode separation the apparent resistivity was determined. A total spread of $400 \mathrm{~m}$ was adopted $(\mathrm{AB} / 2=200 \mathrm{~m})$ with overlaps at $15 \mathrm{~m}$, and $80 \mathrm{~m}$, The necessity for such a simultaneous change in the position of the potential electrodes at the overlapping points was in order to obtain a potential difference large enough to be measured with greater precision. The data so obtained was interpreted using the partial curve matching and a software resistivity interpretation program (offix) which produced resistivities and thicknesses of each layer in the study area

\section{RESULTS AND DISCUSSION}

The results of the soundings and the interpreted data are given in table 1. From this data an iso-resistivity map of the area under study at $\mathrm{AB} / 2=80 \mathrm{~m}$ was produced as shown in figure 2 . Iso-resistivity contour map was obtained by plotting the resistivity values as obtained from the sounding curves at a given electrode spacing common to all the sounding points, and points of equal resistivity value contoured. This type of map shows variation in resistivity with depth at a given area. In the study area, A-type curves constitutes $36.4 \%$ of the total curves obtained and location drilled successfully includes VES07, VES10 and VES11 and the aquifer units are dominantly coarse-grained sand stone at VES10, sandy clay at VES07 and VES11. H -type curves were obtained at VES13 - VES19 and account for $21.2 \%$ of the curve types in the area and locations that were successfully drilled are VES13, VES 16, VES17 and VES 19. HA- type curves were obtained at VES20 - 24 among which only VES22 and 24 were drilled, aquifer material is sandy clay at (VES22) but VES 24 was predominantly clay which resulted in low yield. VES25 and VES28 are HK -type curves and were successfully drilled; the water yielding layer at VES 25 was sand and sandy Clay, while at VES 28, it is a calcareous unit with sand and sandy clay intercalation. Good yield was also obtained at locations with Q -type curves (VES29 and VES30). $\mathrm{KH}-$ type curves were drilled at VES33 which also produces enough ground water in the area.

The iso-resistivity map produced seven major anomalies and two minor ones, a high resistivity northeast - southwest trending anomaly of about $20 \mathrm{~km}$ wide was obtained in the north, and this closure has a resistivity range of 800 - slightly greater than $2200 \mathrm{ohm} \mathrm{m}$. Another anomaly with resistivity range of $800-2000 \mathrm{ohm} \mathrm{m}$ was found in the north-eastern part of the study area and VES 15 which falls on this closure was drilled to a depth of $38 \mathrm{~m}$, the lithology was mainly medium to

* Corresponding author: Arabi, A. S. 
coarse-grained sandstone with thin beds of clay. Anomalies that were borehole supportive were obtained at the northeast at VES10 and VES19, and around the center at VES29, 30, 17 and 33, these are locations that prove to be the best in terms of groundwater prospecting, resistivities here ranges from $100-600 \mathrm{ohm} \mathrm{m}$. VES 27, 25 and 28 falls within the two minor closures where productive wells were successfully drilled. Generally, high resistivity anomalies were found in the northwest at VES 04 and 06, in the southeast at VES 09, in the northeast at VES12 and 15, and the northern part of the study area at VES 20, 32, and 31, (Fig. 2).

It can be conclude from this study that, at a probing depth of $\mathrm{AB} / 2=200 \mathrm{~m}$, the study area is made up of both three and four layer earth models with resistivities of varying ranges.

Bima Formation has shown the best hydrogeological proportions and being arenaceous and fairly permeable, it is the most reliable target for ground water development in the study area. The recharge of this Bima aquifer mainly occurs by infiltration of surface run off in the outcrop area. Lateral recharge is possible through contacts with other formations; it gave the best hydro geological result among the performed boreholes. Some aquifers in the Bima Formation were artesian or semi confined by shale of the Yolde formation, or by silt, clayey and sandy silt levels of the same Bima formation. The Yolde formation shows alternate of Shale, siltstone with intercalated fine sand stone and limestone towards the bottom. The Gombe Formation present high percentage of silt and clay fractions in the siltstone and limestone layers respectively. Therefore its recharge by the overlying Kerri-Kerri Formation is likely to be drastically reduced. On the other hand, the limited out crop area at the Gombe Formation together with the low permeability of its strata reduces the direct feeding by the surfaces run off. The ground water in the Gombe formation seems to occur mainly under water table conditions within the study area. An average depth of $53.6 \mathrm{~m}$ was drilled and the average water table is $19.2 \mathrm{~m}$, average $\mathrm{pH}$ value is 7.03 and conductivity is $68.19 \mathrm{ohm} \mathrm{cmP}^{-1 \mathrm{P}}$. Hydraulic head was identified from the hydraulic head values indicating that the direction of groundwater flow is along northwest - southeast direction. This study has provided relevant information on the resistivities, thickness and depth to layers that host ground water (aquifers) in the study area. Possible ground water flow direction has also been determined. Thus, this piece of information will be very relevant to those charged with the responsibility of planning an effective water supply scheme for Gombe and its environment.

Aknowledgements: The authors are greatly indebted to Mr. Rotimi Ibinola of Gombe State Water Resources and Sanitation Agency and Jarati Nigeria Limited for providing geologic information on some of the locations and software interpretation program.

\section{REFERENCES}

Carter, J.D; Barber, W; and Tait, E. A (1963). The Geology of parts of Adamawa, Bauchi and Bornu provinces in north-eastern Nigeria. Geological Survey of Nigeria, Bulletin No. 30

Interpex, Ltd. (1990). Offix resistivity interpretation program. Campus geophysical instrument. Colorado.

Kollert, R (1969). Groundwater exploration by the electrical resistivity method. Geophysical memorandum ABEM printed matters (90019). Sweden. 